\title{
Australian Journal of Crop Science \\ Geotextiles influence on the formation of soil wet bulbs and the production of drip-irrigated lettuce
}

\author{
Priscilla Lacerda, Paulo Márcio Fernandes Viana*, Gisele Carneiro da Silva, Itamar Rosa Teixeira
}

State University of Goiás, Unity of Anápolis, 75132-400, Anápolis-GO, Brazil

\section{*Corresponding author: paulo@Itec.eng.br}

\begin{abstract}
The influence of nonwoven geotextiles on the formation of wet bulbs and on the vegetative development of $\mathrm{cv}$. Vanda lettuce was evaluated. The study was conducted in a greenhouse using a complete randomized block design with five repetitions. Treatments consisted of a control and three geotextiles grammages: N26.1, N30.1 and N40.1. To evaluate soil wet bulbs, 16 tensiometers were used. They were spaced $5 \mathrm{~cm}$ apart at depths $10,20,30$ and $40 \mathrm{~cm}$. Soil moisture readings were taken before and 2, 12, 24 and 48 hours after irrigation. Each lettuce vegetative development treatment was assessed by evaluations conducted every five days regarding largest leaf length and width, largest width among leaves and number of leaves. At the end of the cycle, fresh and dry shoot and root biomass were weighted to calculate the crop yield. In the formation of soil wet bulbs, the treatment that presented the best water distribution at the assessed depths was the treatment with geotextile N40.1. The highest values of vegetative parameters of lettuce were observed for the treatment with geotextile N40.1, with the largest leaf length. The highest number of leaves per plant was observed 20 days after transplanting (DAT).
\end{abstract}

Keywords: Irrigation efficiency; subsurface drip; use of geotextiles; yield; Lactuca sativa L.

Abbreviations: PB_Physical Barrier, BD_randomized blocks, DAS_days after sowing, DAT_days after transplanting, NWG_ nonwoven geotextiles, SDI_subsurface drip irrigation, UD_distribution uniformity.

\section{Introduction}

Lettuce (Lactuca sativa L.) is regarded as one of the most cultivated vegetables in the group of leafy vegetables. It is consumed in many countries, especially in America, Europe and Asia. It belongs to the Asteraceae family and is native to the Mediterranean region (Kř́stková et al., 2008). It is almost exclusively used as salad, as a vegetable in salads. It is rich in fibers $(95 \%)$ and water and has low calories and nutrients (Mou, 2008). The leaf is of economic interest, and the types of cultivated lettuce are extremely diverse around the world, such as "Butterhead lettuce", "Crisphead lettuce", "Cos lettuce", "Cutting lettuce", "Stalk (Asparagus) lettuce", "Latin lettuce" and "Oilseed lettuce" (Lebeda et al., 2007). The farm-cultivated lettuce are grown usually close to large consumer centers. This proximity to consumer center are called "green belts". Its cultivation uses irrigation.

Drip irrigation is one of the technologies that are increasingly expanding in modern irrigated agriculture, with a great potential regarding water use efficiency. Drip systems allow a judicious water use for a variety of crops. Emitters arranged directly on the soil surface/subsurface allow a low soil volume infiltration. They are known as soil wet bulbs (Moncef and Khemaies, 2016).

In drip irrigation, wet bulbs can be defined as the volume of soil moistened by an issuer or a drip emitter. The shape and size of the wet bulb depend mainly on properties and the physical soil profile for a given soil, applied water volume, flow of the issuer and the land (Fernandez-Galvez and Simmonds, 2006; Wei et al., 2011). The evaluation of water dynamics and the characterization of the formed soil wet bulb generate important information for the design of localized irrigation projects (drip and micro sprinkler). It is also important for a rational management of water at the implementation of such projects. This minimizes losses due to percolation and the formation of saline fronts, thus maximizing the water use efficiency by irrigated crops and helping to reduce the environmental impact of irrigation, by either reducing the potential of groundwater contamination or minimizing soil salinization processes (Dabral et al., 2012). Among systems used, subsurface drip irrigation (SDI) is stressed. In SDI, water is applied directly to the plant root zone, keeping the soil moisture in this region close to field capacity, resulting in reduced water evaporation losses, incidence of pests and diseases and environmental contamination risks, in addition to increased crop yield opportunities (Singh et al., 2006; Rajput and Patel, 2009; Parkes et al., 2010). However, some factors may limit the adoption of subsurface drip, such as blockage of system emitters by soil particles (clogging) and the tendency of roots to concentrate in the wet bulb generated by the emitter (root intrusion) (Dalri and Cruz, 2002; Coelho et al., 2007).

One way to avoid subsurface drip clogging and intrusion problems, which have been researched in recent years because of its easy adoption, in addition to a good costbenefit ratio, is the use of Physical Barriers (PB) in this irrigation system (Hernandez, 2010; Mosca et al., 2005).

The formation of physical barriers through the setting of nonwoven geotextiles (NWG) made from polypropylene fibers by needling stands out among viable alternatives. NWGs have an advantageous three-dimensional structure, especially regarding filtration, protection and separation 
functions. Due to its high permeability, it allows fluids to pass through its structure while retaining soil particles. It also has good mechanical properties, providing it with a good adaptability to soil discontinuities (Silva et al., 2011).

Despite NWGs' advantages, when used as a PB, it is necessary to verify its influence on irrigation system efficiency, especially with regard to the formation of soil wet bulbs, since this can be a factor limiting crop development. However, agricultural studies involving the use of geotextiles do not exist in the scientific literature. This study aimed to evaluate the influence of three nonwoven geotextile grammages on the formation of soil wet bulbs and the development of cv. Vanda lettuce in a subsurface drip irrigation system.

\section{Results and Discussion}

\section{Soil wet bulb formation}

Soil moisture before treatments was approximately $20 \mathrm{kPa}$, with a higher tension than this value in the first $20 \mathrm{~cm}$ of soil (Fig. 1), which is therefore less than the corresponding moisture at field capacity characterized as the ideal irrigation time for a maximum crop yield (Bandeira et al., 2011). The highest soil moisture, which is characterized by lower tensions, was observed between the depth 0 and $30 \mathrm{~cm}$. The lowest soil moisture was observed in deeper than $30 \mathrm{~cm}$ depths, except for the upper left corner, where the presence of water was observed, although in a restricted area. This did not interfere with the analysis.

In readings taken 2 hours after irrigation, the soil tension was between 5.4 and $14 \mathrm{kPa}$ in all treatments (Fig. 2). It was observed that in the control (Fig. 2a), despite a higher soil moisture uniformity in the surface area, there were saturation areas in the first $20 \mathrm{~cm}$ (values $<6 \mathrm{kPa}$ ). This is an unfavorable condition for the vegetative growth of lettuce because it favors diseases and increases nutrient leaching problems and unnecessary expenses with the water and the energy used in irrigation (Lima-Júnior et al., 2010). In the treatment NWG N26.1, there was a centralized initial infiltration because the central part had a wet vertical area. However, in areas at the bottom, there was less moisture compared to the center (Fig. 2b). This may be related to the fact that more remote areas, such as the one located $20 \mathrm{~cm}$ from the emitter, were not yet humidified two hours after irrigation.

In the treatment NWG N30.1 (Fig. 2c), a wet nuclear zone was observed, resulting in a moisture uneven uniformity compared with other evaluated distances. This may cause the development of uneven plants in a same planting area. According to Juchen et al. (2013), irrigation uniformity is considered one of the most important factors in the design and operation of irrigation systems since it direct affects crops yield. In the treatment NWG N40.1, which has the highest grammage and a low water flow nonwoven geotextile, there were wetter superficial and central zones near the emission point. According to different distances, the moisture decreases, although equitably, in all areas. This was different from what was observed for the lighter grammage NWG and higher water flow treatments (Fig. 2d).

In readings performed 12 hours after irrigation (Fig. 3), the control and the treatment NWG N26.1 showed tendencies similar to those observed for assessments performed two hours after irrigation. In the control (Fig. 3a), there was an acute loss of water on the surface and in distant points (20 $\mathrm{cm}$ ) from the dripper emitter. In the wet bulb formed by the treatment NWG N30.1 (Fig. 3c), there was a more uniform moisture distribution at depth and at more distant emitters when compared to the control and to the treatment NWG N26.1. This may be related to the lower water flow of this treatment, which causes gradual water availability, reducing water loss and contributing to a better water distribution in the bulb (Souza and Matsura, 2004). In Fig. 3d, it can be seen that in the treatment NWG N40.1, there was water loss because its lines were vertical. It had a low water percolation, since it was not enough to remove the moisture from the field capacity of the assessment area, considered ideal for tropical soils.

In the reading performed 24 hours after irrigation (Fig. 4), a higher water percolation was observed in the control in the first $15 \mathrm{~cm}$, with soil moisture below field capacity. This tendency was not observed for N26.1, 30.1 and 40.1 NWG, which kept area humidity with a slight soil tension variation (increase of approximately $2 \mathrm{kPa}$ ) and a higher water content uniformity. Thus, it was observed that 24 hours after the irrigation of the control, there was a more accentuated moisture loss at the surface zone, while treatments with nonwoven geotextiles kept moisture and uniformity more efficiently.

In the last reading, performed 48 hours after irrigation (Fig. 5), there were soil tension differences among treatments. As observed in previous readings, the control showed a high percolation and a significant soil water content reduction, especially in the first $25 \mathrm{~cm}$ of depth. The reading was above $20 \mathrm{kPa}$, thus with a moisture content below field capacity. This indicates the need for crop irrigation. In the treatments with nonwoven geotextiles (N26.1, N30.1, N40.1), it could be seen that there was no significant moisture reduction compared with the previous reading ( 24 hours). This may be attributed to soil water retention capacity for a longer period when compared to the control, which, in most of the studied depths, increased tension by $10 \mathrm{kPa}$ and had a high water content uniformity. This is an important condition to obtain a better crop performance.

The content and distribution of the water available in the soil varied between geotextile treatments and the control in the readings taken 12 hours after irrigation. Regardless of assessment times after irrigation, synthetic materials provided a better maintenance and water distribution in the wet bulb when compared to the control. However, because they have different technical characteristics, such as water flow and permeability, results of water tension in the soil also differed among geotextile treatments. This is because, during evaluations, especially at the beginning, these specificities influenced on the water distribution of wet bulbs formed in the soil. Lubana and Narda (1998) pointed out that knowing the soil moisture distribution for different emitters flow rates and irrigation times is of paramount importance to a drip irrigation design, and that flow rate and time, along with the soil type, influence water movement and subsequently crop development.

\section{Lettuce crop development}

The length of lettuce leaves did not vary significantly among treatments for assessments performed at 5, 10, 15 and 20 days after transplanting (Table 1). However, in the evaluation made 20 days after transplanting, this agronomic characteristic differed among treatments, and the highest value was observed in the treatment N40.1 compared to the other treatments. This result may be related to the fact that this treatment formed wet bulbs with a better water content 
Table 1. Leaf length, leaf width, number of leaves per plant and increased distance between the leaves of lettuce plants under different physical covers of a dripline subsurface irrigation system

\begin{tabular}{|c|c|c|c|c|c|c|c|c|}
\hline & \multicolumn{4}{|c|}{ Leaf length $(\mathrm{cm})$} & \multicolumn{4}{|c|}{ Leaf width $(\mathrm{cm})$} \\
\hline \multirow[t]{2}{*}{ Geotextile } & 5 & 10 & 15 & 20 & 5 & 10 & 15 & 20 \\
\hline & \multicolumn{4}{|c|}{ Days after transplanting } & \multicolumn{4}{|c|}{ Days after transplanting } \\
\hline Control & $13.28 \mathrm{a}$ & $14.96 \mathrm{a}$ & $15.03 \mathrm{a}$ & $15.63 \mathrm{bc}$ & $10.95 a$ & $11.71 \mathrm{a}$ & $13.91 \mathrm{a}$ & $15.05 \mathrm{a}$ \\
\hline N 26.1 & $12.64 \mathrm{a}$ & $13.87 \mathrm{a}$ & $14.98 \mathrm{a}$ & $14.52 \mathrm{c}$ & $9.74 \mathrm{a}$ & $11.41 \mathrm{a}$ & $12.78 \mathrm{a}$ & $13.94 \mathrm{a}$ \\
\hline N 30.1 & $12.95 \mathrm{a}$ & $14.28 \mathrm{a}$ & $15.48 \mathrm{a}$ & $16.52 b$ & $10.40 \mathrm{a}$ & $11.99 \mathrm{a}$ & $13.84 \mathrm{a}$ & $13.90 \mathrm{a}$ \\
\hline \multirow[t]{2}{*}{$\mathrm{N} 40.1$} & $14.10 \mathrm{a}$ & $15.08 \mathrm{a}$ & $15.73 \mathrm{a}$ & $17.35 \mathrm{a}$ & $10.45 \mathrm{a}$ & $11.90 \mathrm{a}$ & $13.15 \mathrm{a}$ & $15.11 \mathrm{a}$ \\
\hline & \multicolumn{4}{|c|}{ Number of leaves per plant } & \multicolumn{4}{|c|}{ Longest distance between leaves $(\mathrm{cm})$} \\
\hline \multirow[t]{2}{*}{ Geotextile } & 5 & 10 & 15 & 20 & 5 & 10 & 15 & 20 \\
\hline & \multicolumn{4}{|c|}{ Days after transplanting } & \multicolumn{4}{|c|}{ Days after transplanting } \\
\hline$\overline{\text { Control }}$ & $5.15 a$ & $6.90 \mathrm{a}$ & $9.25 \mathrm{a}$ & $12.25 \mathrm{~b}$ & $22.51 \mathrm{a}$ & $24.45 a$ & $28.66 a$ & $28.27 b$ \\
\hline N 26.1 & $4.95 \mathrm{a}$ & $6.45 \mathrm{a}$ & $9.15 \mathrm{a}$ & $11.90 \mathrm{~b}$ & $20.88 \mathrm{a}$ & $22.51 \mathrm{a}$ & $24.74 b$ & $26.47 \mathrm{c}$ \\
\hline N 30.1 & $4.60 \mathrm{a}$ & $6.10 \mathrm{a}$ & $9.10 \mathrm{a}$ & $12.85 \mathrm{~b}$ & $21.12 \mathrm{a}$ & $23.95 \mathrm{a}$ & $24.71 b$ & $29.85 \mathrm{~b}$ \\
\hline Cont. & & & & & & & & \\
\hline $\mathrm{N} 40.1$ & $4.80 \mathrm{a}$ & $6.00 \mathrm{a}$ & $9.30 \mathrm{a}$ & $14.55 \mathrm{a}$ & $23.02 \mathrm{a}$ & $26.32 \mathrm{a}$ & $28.12 \mathrm{a}$ & $33.15 \mathrm{a}$ \\
\hline
\end{tabular}

* Means followed by the same letter do not differ significantly by Tukey's test at $5 \%$ probability.

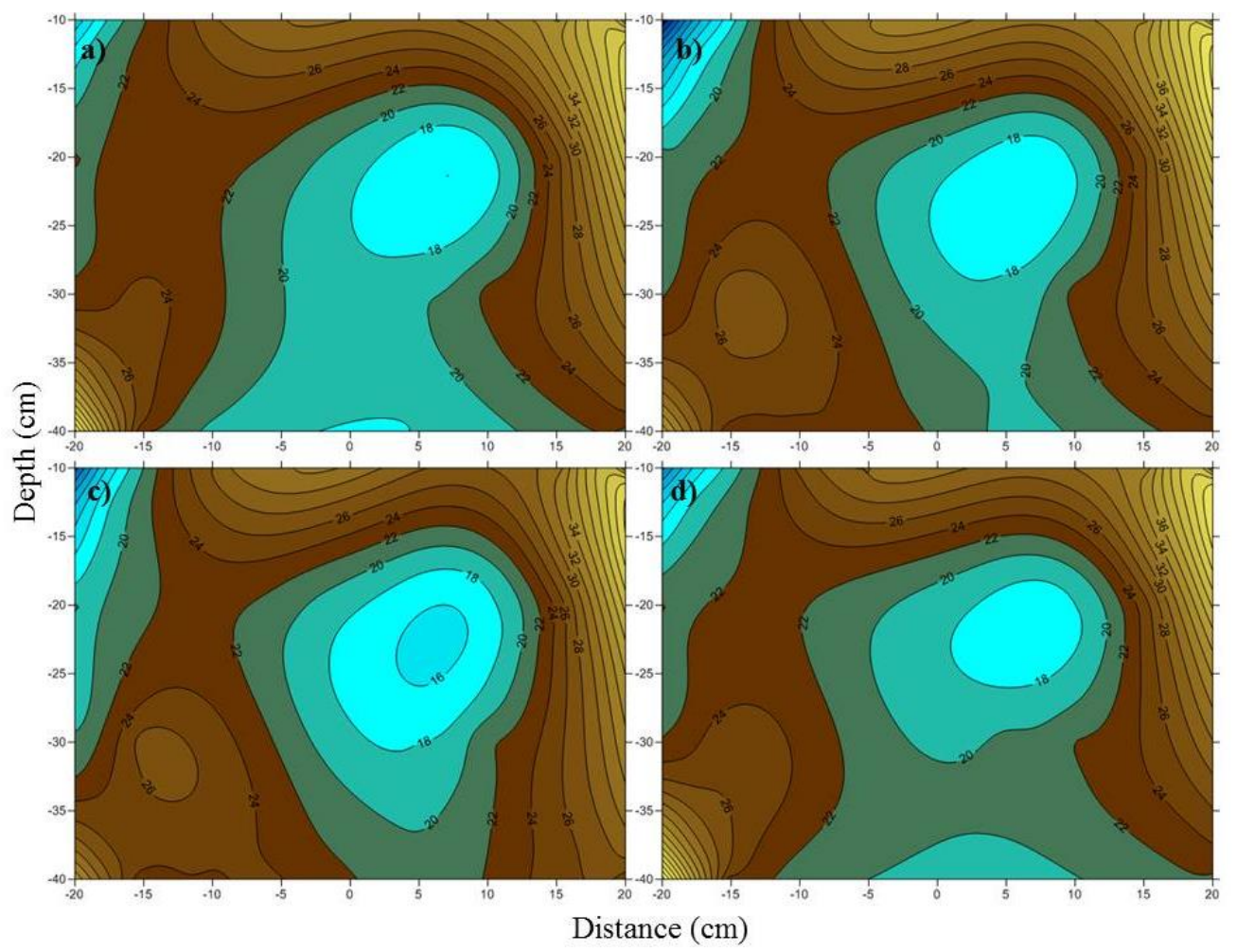

Fig 1. Soil water content before irrigation in the following treatments: a) control, b) N26.1 geotextile, c) N30.1 geotextile, and d) N40.1 geotextile.

distribution on tensiometer assessments after irrigation and kept the moisture for a longer period if compared to the other treatments. The lowest values were observed in the treatment N26.1. Lima-Junior et al. (2012), upon evaluating the effect of different water depths on the productive characteristics of the American Laureau cultivar, concluded that the best leaf crop development occurred in a corresponding water depth replacement of $98 \%$ of evaporated water, reflecting the high water demand for this crop's development.

The distance between lettuce plant leaves was influenced by the treatments, with the highest values being observed for the control and the treatment NGW 40.1 in assessments performed at 15 and 20 days after transplanting (Table 1). The lowest average distance between leaves was observed in the treatment NGW N26.1, regardless of the interval after transplanting considered. This can be attributed to an uneven uniformity of soil moisture in wet bulb analyses performed at 12, 24 and 48 hours after irrigation (Figs. 3, 4 and 5). Leafy vegetables, such as lettuce, perform better under soil water tensions closer to field capacity and with a more uniform water distribution in the wet bulb. Bandeira et al. (2011), evaluating the productive behavior of lettuce cultivars AF 1743 and OGR 326 under different irrigation management systems, observed that water stress reduced the accumulation of photosynthate and the productivity of cultivars. A same tendency was observed for the number of leaves/lettuce plant and lettuce plants height (Table 1), in which N40.1 and N26.1 geotextiles provided the highest and lowest values, 
Table 2. Fresh matter, yield, water depth and water use efficiency under different physical covers of a dripline subsurface irrigation system.

\begin{tabular}{|c|c|c|c|c|}
\hline Treatments & $\begin{array}{c}\text { Fresh matter } \\
\left(\text { g planta }^{-1}\right)\end{array}$ & $\begin{array}{c}\text { Yield } \\
\left(\mathrm{kg} \mathrm{ha}^{-1}\right)\end{array}$ & $\begin{array}{l}\text { Water depth } \\
(\mathrm{mm})\end{array}$ & $\begin{array}{c}\text { Water use efficiency } \\
\left(\mathrm{kg} \mathrm{ha}^{-1} \mathrm{~mm}^{-1}\right)\end{array}$ \\
\hline Control & $138.39 \mathrm{a}$ & $8.452 .48 \mathrm{a}$ & 93.2 & $90.69 \mathrm{a}$ \\
\hline N 26.1 & $140.26 \mathrm{a}$ & $8.857 .34 \mathrm{a}$ & 93.2 & $95.03 \mathrm{a}$ \\
\hline N30.1 & $132.07 \mathrm{a}$ & $8.977 .02 \mathrm{a}$ & 93.2 & $96.31 \mathrm{a}$ \\
\hline N40.1 & $173.32 \mathrm{a}$ & $11.092 .86 \mathrm{a}$ & 93.2 & $119.02 \mathrm{a}$ \\
\hline
\end{tabular}

* Means followed by the same letter do not differ significantly by Tukey's test at $5 \%$ probability.

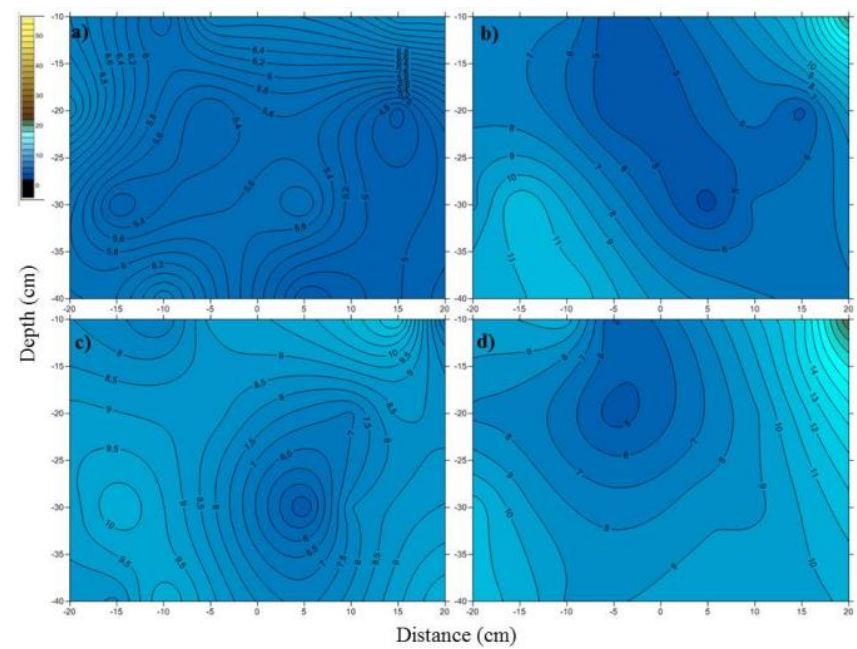

Fig 2. Soil water content two hours after irrigation in the following treatments: a) control, b) N26.1 geotextile, c) N30.1 geotextile and d) N40.1 geotextile.

Table 3. Leaf and stem fresh matter, root fresh matter, leaf and stem dry matter and root dry matter under different physical covers of a dripline subsurface irrigation system.

\begin{tabular}{|c|c|c|c|c|}
\hline & Parameters & & & \\
\hline Geotextile & $\begin{array}{l}\text { Leaf and stem } \\
\text { matter }\end{array}$ & $\begin{array}{l}\text { freshRoot fresh matter } \\
\text { (g) }\end{array}$ & Leaf and stem dry matter & Root dry matter \\
\hline Control & $138.39 \mathrm{a}$ & $3.81 \mathrm{~b}$ & $7.35 \mathrm{a}$ & $1.00 \mathrm{a}$ \\
\hline N 26.1 & $140.26 \mathrm{a}$ & $3.37 \mathrm{~b}$ & $7.48 \mathrm{a}$ & $1.03 \mathrm{a}$ \\
\hline N 30.1 & $132.07 \mathrm{a}$ & $4.34 \mathrm{ab}$ & $6.79 \mathrm{a}$ & $1.15 \mathrm{a}$ \\
\hline $\mathrm{N} 40.1$ & $173.33 \mathrm{a}$ & $5.27 \mathrm{a}$ & $8.15 \mathrm{a}$ & $1.53 \mathrm{a}$ \\
\hline
\end{tabular}

* Means followed by the same letter do not differ significantly by Tukey's test at $5 \%$ probability.

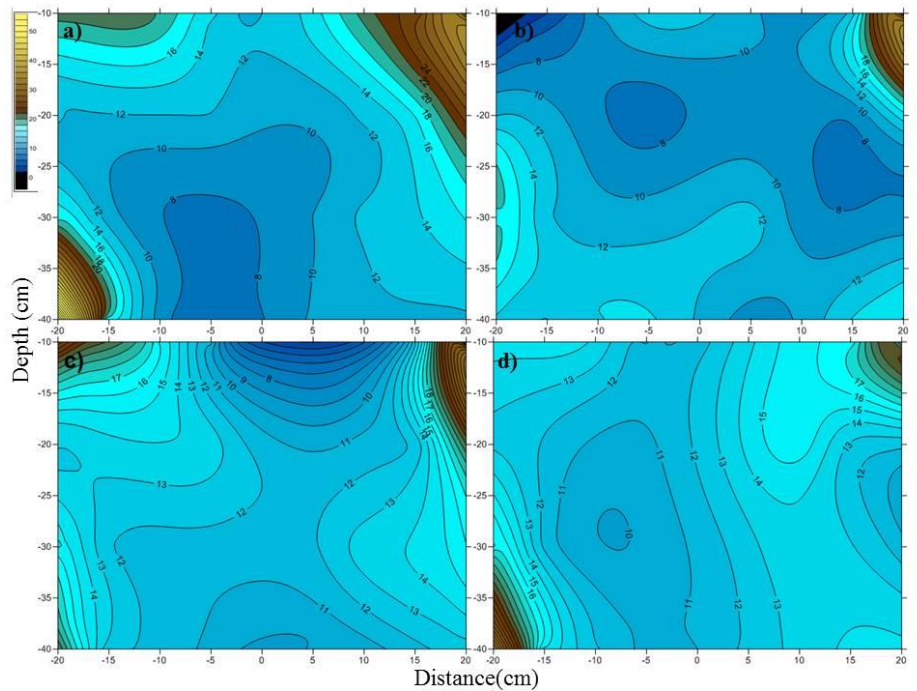

Fig 3. Soil water content twelve hours after irrigation in the following treatments: a) control, b) N26.1 geotextile, c) N30.1 geotextile and d) N40.1 geotextile. 
Table 4. Physical and chemical characteristics of the soil used in the experiment Physical properties

\begin{tabular}{llllll} 
Depth & Coarse sand & Fine sand & Silt & Clay & Texture class \\
\hline $\mathrm{cm}$ & $\mathrm{g} \mathrm{kg}^{-1}$ & & & & \\
$0-20$ & 275 & 324 & 241 & 160 & Sandy loam \\
$21-40$ & 329 & 283 & 202 & 186 & Sandy loam \\
Chemical properties & & & & \\
\hline
\end{tabular}

\begin{tabular}{|c|c|c|}
\hline \multirow{2}{*}{ Variables } & \multicolumn{2}{|c|}{ Depth (cm) } \\
\hline & $0-20$ & $21-40$ \\
\hline $\mathrm{pH} \mathrm{H} \mathrm{H}_{2} \mathrm{O}(1: 1,25)$ & 6.5 & 6.5 \\
\hline $\mathrm{P}-\mathrm{Melich}\left(\mathrm{mg} \mathrm{dm}{ }^{3}\right)$ & 48.3 & 49.2 \\
\hline $\mathrm{K}\left(\mathrm{mg} \mathrm{dm}^{3}\right)$ & 42 & 24 \\
\hline $\left.\mathrm{S}-\mathrm{SO}_{4}(\mathrm{mg} \mathrm{dm})^{3}\right)$ & 45 & 48 \\
\hline $\mathrm{Ca}\left(\mathrm{cmol}_{\mathrm{c}} \mathrm{dm}^{3}\right)$ & 4.8 & 3.4 \\
\hline $\operatorname{Mg}\left(\mathrm{cmol}_{\mathrm{c}} \mathrm{dm}^{3}\right)$ & 1.3 & 0.9 \\
\hline $\mathrm{Al}\left(\mathrm{cmol}_{\mathrm{c}} \mathrm{dm}^{3}\right)$ & 0.0 & 0.0 \\
\hline $\mathrm{H}+\mathrm{Al}\left(\mathrm{cmol}_{\mathrm{c}} \mathrm{dm}^{3}\right)$ & 2.2 & 2.0 \\
\hline $\mathrm{B}\left(\mathrm{mg} \mathrm{dm}^{3}\right)$ & 0.1 & 0.07 \\
\hline $\mathrm{Cu}\left(\mathrm{mg} \mathrm{dm}^{3}\right)$ & 2.4 & 1.2 \\
\hline $\mathrm{Fe}\left(\mathrm{mg} \mathrm{dm}^{3}\right)$ & 51 & 23 \\
\hline $\operatorname{Mn}\left(\mathrm{mg} \mathrm{dm}^{3}\right)$ & 6.9 & 3.9 \\
\hline $\mathrm{Zn}\left(\mathrm{mg} \mathrm{dm}^{3}\right)$ & 0.8 & 1.9 \\
\hline M.O. $\left(\right.$ dag kg $\left.^{-1}\right)$ & 1.8 & 1.3 \\
\hline
\end{tabular}

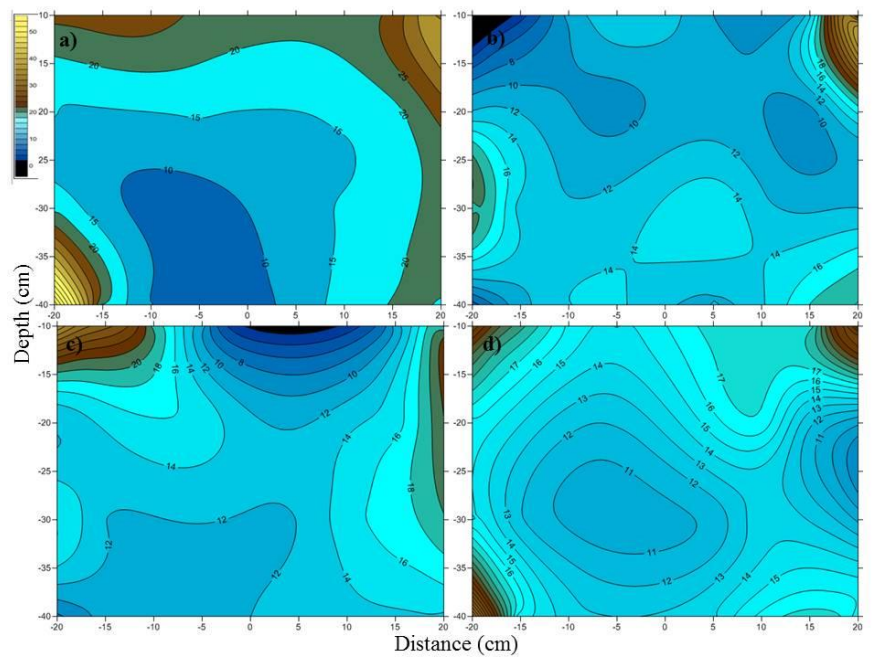

Fig 4. Soil water content twenty four hours after irrigation in the following treatments: (a) control, (b) N26.1 geotextile, (c) N30.1 geotextile and (d) N40.1 geotextile. 
Table 5. Main technical characteristics of nonwoven geotextiles used in the experiment

\begin{tabular}{llll}
\hline Technical characteristics & \multicolumn{3}{c}{ Nonwoven geotextile types } \\
\hline & $\mathrm{N} \mathrm{26.1}$ & $\mathrm{N} \mathrm{30.1}$ & $\mathrm{N} 40.1$ \\
Grammage $\left(\mathrm{g} / \mathrm{cm}^{2}\right)$ & 120 & 150 & 210 \\
Longitudinal tear resistance $(\mathrm{KN})$ & 0.16 & 0.22 & 0.29 \\
Overflow resistance $(\mathrm{kPa})$ & 1035 & 1554 & 1930 \\
Normal permeability $(\mathrm{cm} / \mathrm{s})$ & 0.45 & 0.45 & 0.42 \\
Water flow $\left(\mathrm{L} / \mathrm{seg} . \mathrm{m}^{2}\right)$ & 153 & 136 & 102 \\
Apparent openness $(\mathrm{mm})$ & 0.300 & 0.250 & 0.212 \\
\hline
\end{tabular}

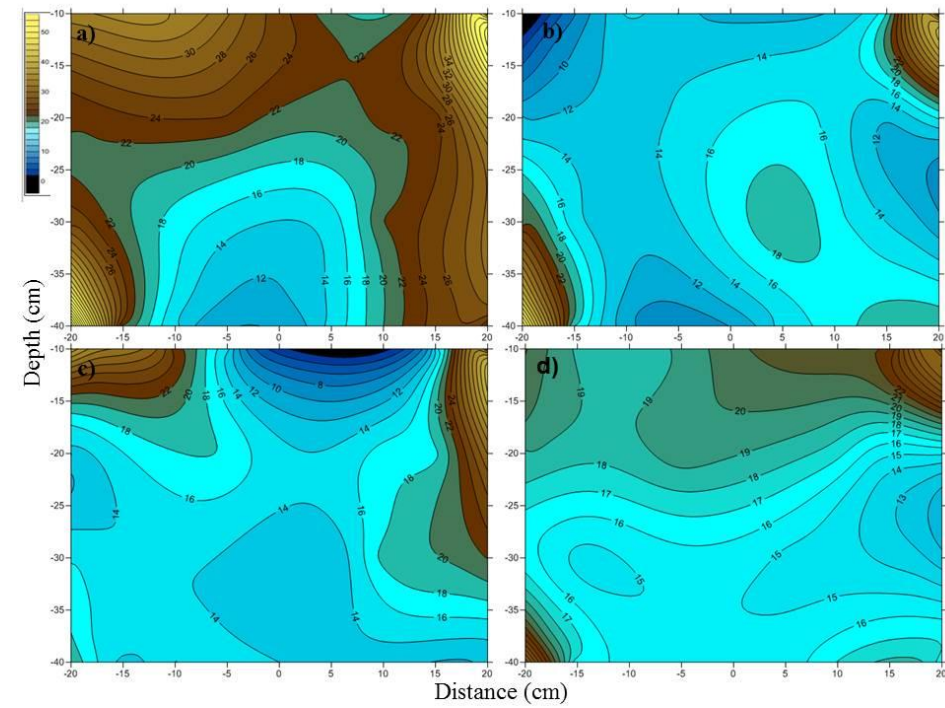

Fig 5. Soil water content forty eight hours after irrigation in the following treatments: a) control, b) N26.1 geotextile, c) N30.1 geotextile and d) N40.1 geotextile.

respectively, regardless of transplanting time. Despite the observed variation in leaf length and plant height in the treatment N40.1, leaf and stem fresh matter and cultivar productivity were not significantly influenced by nonwoven geotextiles using needles as physical protectors of irrigation system emitters (Table 2). There were no differences among treatments as to leaf, stem and root dry matter (Table 3). However, lettuce root fresh matter was influenced in function of treatment type. The highest root fresh matter was observed in the treatment N40.1 if compared to the other treatments.

The nonwoven geotextile of the treatment N40.1 was thicker, creating a saturated barrier that kept the moisture in the wet bulb for a longer period and, as a planar/perimeter structure, it kept the system uniform, taking into account that the evaporation phenomenon is minimal in greater depths. Thus, a geotextile with an increased grammage acts as a water reservoir for plant roots. In wet bulb analyses of the control, a moisture above field capacity in surface areas was observed between irrigations. This may have contributed to the lower numerical value of fresh matter production rate observed among treatments. The opposite was observed for the N40.1 geotextile treatment, in which the surface area remained wetter and uniform in bulbs formed 24 and 48 hours after irrigation when compared to the control, resulting in a higher numerical value of dry matter production rate.

\section{Materials and Methods}

\section{Plant materials}

The experiment was conducted under greenhouse conditions in July to August 2014 at the Goiás Federal Institute of Education, Science and Technology, Campus Urutaí, GO, Brazil, whose geographical coordinates are: $15^{\circ} 29^{\prime} 53^{\prime \prime} \mathrm{S}$, $49^{\circ} 41^{\prime} 15^{\prime \prime} \mathrm{W}$ and at $586 \mathrm{~m}$ altitude. The climate, ccording to the Köppen classification, is Cwb (tropical of altitude), featuring two distinct seasons, with a dry winter and a rainy summer. The soil of the experimental area was classified as a Ferralsol (Embrapa, 1999), with a sandy loam texture. Soil chemical and physical analysis was performed with a composite sample formed by five single samples collected inside the greenhouse at depths $0-20$ and $21-40 \mathrm{~cm}$. Soil physical and chemical characteristics for each depth are shown in Table 4.

\section{Treatments}

The geotextiles used are comprised of a chemical textile fiber (polypropylene). The main technical characteristics of NWGs used in this study are described in Table 5. The experimental design was a randomized block design (RBD) with four treatments: control and N26.1, N30.1 and N40.1 geotextiles and five replications. Plots had a $10 \mathrm{~m}$ length and a $1 \mathrm{~m}$ width, consisting of two drip lines each buried at a $0.10 \mathrm{~m}$ depth.

\section{Soil characterization}

To obtain the water retention curve, an undisturbed soil sample was collected using volumetric rings at the layers 010 and $11-20 \mathrm{~cm}$. The determination of the characteristic retention curve of soil water was performed according to the method by Camargo et al. (2009), adjusted by the method by Van Guenuchten (1980).

In each plot, which consists of two planting lines, a located drip subsurface irrigation system was used. In each of the two lines, a lateral irrigation line with a $16 \mathrm{~mm}$ diameter and emitters spaced $0.3 \mathrm{~m}$ each were installed. Emitters provided 
a flow rate of $1.6 \mathrm{~L} \mathrm{~h}^{-1}$ and worked with a 10 mca operating pressure. The pumping system consisted of a $1 \mathrm{hp}$ pump set. Irrigation was performed based on a "class A tank" evaporimeter, with 48 hours of irrigation interval and irrigation time at 6 o'clock.

Crop evapotranspiration was determined according to Eq 1.

$\mathrm{ETc}=\mathrm{ETo} \times \mathrm{Kc}$

Where:

ETc $=$ crop evapotranspiration $\left(\mathrm{mm} \mathrm{day}^{-1}\right)$

$\mathrm{ETo}=$ reference evapotranspiration $\left(\mathrm{mm} \mathrm{day}^{-1}\right)$

$\mathrm{Kc}=$ crop coefficient (dimensionless)

The used crop coefficient $(\mathrm{Kc})$ varied according to the development stage of the crop, and the following values were considered: 0.48 - from transplanting to 15 days of development; 0.80 - from 15 to 30 days; and 1.0 - to the development phase between 30 days after transplanting and harvesting.

To determine water application uniformity, drip flow rates were measured along the lateral lines with a precipitation kit, with collectors measuring $8 \mathrm{~cm}$ in diameter and $10.2 \mathrm{~cm}$ in height. The collection time was eight minutes, determined with a precision stopwatch and a cylinder graduated in $\mathrm{mL}$. The flow rate was determined by the volumetric method, which, according to Salomão (2008), may be used for a small volume collection according to Eq. 2.

$Q=\frac{\mathrm{V} / 1000}{\mathrm{~T} / 60}$

Where:

$\mathrm{Q}=$ flow rate $\left(\mathrm{L} \mathrm{h}^{-1}\right)$

$\mathrm{V}=$ collected volume $(\mathrm{mL})$

$\mathrm{T}=$ collection time $(\mathrm{min})$

The irrigation system uniformity was determined following the methodology proposed by Denículi et al. (1980), adapted to experimental plots. Water collection was performed in four drippers along the lateral line. It was performed in the first dripper, in the drippers located at $1 / 3$ and $2 / 3$ of the line and in the last dripper. This procedure was carried out in each experimental block.

Water application uniformity was assessed by the distribution uniformity index, which is calculated by dividing the $25 \%$ lowest flow average by the average of all observed flows (Eq. 3 ). The $91 \%$ distribution uniformity average value in the test was obtained. According to criteria presented by Asae (1996), it means that the system has an optimal water application.

$\mathrm{UD}=100 * \frac{\mathrm{q}_{25} \%}{\mathrm{q}}$

Where:

$\mathrm{UD}=$ distribution uniformity $(\%)$

$\mathrm{q}_{25 \%}=$ average of the $25 \%$ lowest flow rate values observed $\left(\mathrm{L} \mathrm{h}^{-1}\right)$

Since no irrigation system has a $100 \%$ efficiency, water depth correction was needed. It was adjusted according to the determined distribution uniformity, with a value of $91 \%$. Then, the water depth was calculated by Eq. 4 .

$\mathrm{L}_{\mathrm{i}}=\frac{\mathrm{ETc}}{\mathrm{UD}}$

Where:

$\mathrm{Li}=$ irrigation depth $(\mathrm{mm})$

ETc $=$ crop evapotranspiration $\left(\mathrm{mm} \mathrm{day}^{-1}\right)$

$\mathrm{UD}=$ distribution uniformity (decimal)
Considering irrigation as a continuous wet range, the operation time of the irrigation system was defined by Eq. 5 . $\mathrm{Ti}=\frac{\mathrm{Li} * \mathrm{El} * \mathrm{Eg}}{\mathrm{q}}$

Where:

$\mathrm{T}_{\mathrm{i}}=$ treatment irrigation time $(\mathrm{h})$

$\mathrm{Li}=$ irrigation depth $(\mathrm{mm})$

$\mathrm{E} 1$ = spacing between lateral lines (nEq. (1)

$\mathrm{Eg}=$ spacing between drippers $(\mathrm{m})$

$\mathrm{Q}=$ dripper flow rate $\left(\mathrm{L} \mathrm{h}^{-1}\right)$

\section{Characteristics measured in plants}

At 29 days after sowing (DAS), seedlings were transplanted, adopting the spacing $0.3 \times 0.3 \mathrm{~m}$. The harvest was performed 35 days after transplanting, moment at which plants had the maximum vegetative growth.

To evaluate lettuce crop vegetative growth, the following variables were measured fourfold every five days after transplanting: number of leaves, longest leaf length, longest leaf width and highest width between leaves. They were determined with a millimeter ruler. At the end of the crop cycle, fresh and dry biomass of shoots and roots were determined with a 0.01 precision analytical scale. The dry biomass was obtained from fresh biomass dried at $65^{\circ} \mathrm{C}$ in a forced air circulation oven until constant mass.

The influence of Geotextiles on each wet bylb 2 formation treatment was evaluated by reading the moisture of 16 tensiometers, which were $5 \mathrm{~cm}$ apart until reaching $20 \mathrm{~cm}$ at depths 10,20, 30 and $40 \mathrm{~cm}$. The distribution of soil water content was determined with moisture readings from five tensiometers in each treatment, performed before and 2, 12, 24 and 48 hours after irrigation, according to Kandelous et al. (2011).

The soil wet bulb in the control treatment was analyzed in bare soil. The irrigation was based on the average obtained in the other experimental treatments $(30$ minutes, $0.8 \mathrm{~L}$ ). It was sufficient to observe soil water movement during 48 hours. The bulb was individually evaluated, i.e., all irrigation line emitters were isolated by involving them with a threaded sealing and an insulating tape, with the exception of one central emitter, in order to avoid overlapping, because, according to the results presented by Kandelous et al. (2011), this requires three-dimensional models.

\section{Statistical analysis}

Data obtained in the vegetative growth stage of lettuce were submitted to analysis of variance an were compared by Tukey's test at $5 \%$ probability. Data were adjusted to regression equations. The formation of wet bulbs was measured by reading means from each tensiometer each hour. Data from different depths $(10,20,30$ and $40 \mathrm{~cm})$ and distances $(5,10,15$ and $20 \mathrm{~cm})$, as established for the treatments, were entered into the Surfer 11 software.

\section{Conclusions}

The results showed that treatments with $\mathrm{N} 26.1, \mathrm{~N} 30.1$ and N40.1 geotextiles kept soil wet bulb moisture for a longer period when compared to the control. The soil wet bulb from the treatment $\mathrm{N} 40.1$ geotextile, in the assessments performed 24 and 48 hours after irrigation, had a uniform distribution and a higher water content available if compared to the other treatments. At 20 days after transplanting, the greatest leaf length, number of leaves per plant and largest width between 
lettuce crop leaves were higher in the treatment N40.1 geotextile.

\section{Acknowledgements}

The authors would like to thank the Goiás IF, Campus Urutaí, for providing resources and professionals to assist in the conduction of the study; to the State University of Goiás for the knowledge and material; and to CAPES for granting the Master's scholarship.

\section{References}

Asae - American Society of Agricultural Engineers (1996) Procedure for measuring distribution uniformity and calibrating granular broadcast spreaders. St. Joseph.

Bandeira GRL, Pinto HCS, Magalhães OS, Aragão CA, Queiroz SOP, Souza ER, Seido SL (2011) Manejo de irrigação para cultivo de alface em ambiente protegido. Hortic Bras. 29:237-241

Camargo's OA, Moniz AC, Jorge JA, Valadares JMAS (2009) Métodos de análise química, mineralógica e física de solos do Instituto Agronômico de Campinas. Inst Agron Camp, Campinas.

Coelho RD, Vilela LAA, Resende RS, Teixeira MB, Sá JS (2007) Entupimento de gotejadores em decorrência de pulsos de partículas sólidas na malha hidráulica. Irriga. 12:108-122.

Dabral, PP, Pandey PK, Ashish P, Singh KP, Sanjoy SM (2012) Modeling of wetting pattern under trickle source in sandy soil of Nirjuli Pradesh (India). Irrig Sci. 30: 287292.

Dalri AB, Cruz RL (2002) Efeito da frequência de irrigação subsuperficial por gotejamento no desenvolvimento da cana-de-açúcar (Saccharum spp.). Irriga. 7:29-34.

Denículi W, Bernardo S, Thiábaut JTL, Sediyamab GC (1980) Uniformidade de distribuição de água, em condições de campo, num sistema de irrigação por gotejamento. Rev Ceres 27: 155-162.

Embrapa -Empresa Brasileira de Pesquisa Agropecuária (1999). Sistema brasileiro de classificação de solos. Brasília.

Fernandez-Galvez J, Simmonds LP (2006) Monitoring and modeling the three-dimensional flow of water under drip irrigation. Agric. Water Manag. 83:197-208.

Hernandez MGR (2010) Proteção de gotejadores a obstrução por intrusão radicular em irrigação subsuperficial de figueiras. Universidade Federal de Santa Maria, Santa Maria.

Juchen CR, Suszek FL, Vilas Boas MA (2013) Irrigação por gotejamento para produção de alface fertirrigada com águas residuárias agroindustriais. Irriga. 18:243-256.

Kandelous MM, Simunek J, Van Genuchten MTH, Malek K (2011) Soil water content distributions between two emitters of a subsurface drip irrigation system. Soil Sci. Soc Am. J. 75:488-497.

Křístková E, Doležalová I, Lebeda A, Vinter V, Novotná A (2008) Description of morphological characters of lettuce (Lactuca sativa L.) genetic resources. Hort Sci. 35:113-129 113.
Lebeda A, Ryder EJ, Grube R, Doležalov ÁI, Křístková E (2007) Lettuce (Asteraceae; Lactuca spp.). In: Singh RJ (eds) Genetic resources, chromosome engineering, and crop improvement, v.3, Vegetable crops. Boca Raton.

Lima Júnior JA, Pereira GM, Geisenhoff LO, Costa GG, Vilas Boas RC, Yurii JE (2010) Efeito da irrigação sobre o rendimento produtivo da alface americana, em cultivo protegido. Rev Bras Eng Agríc Ambient. 14:797-803.

Lima Júnior JA, Pereira GM, Geisenhoff LO, Vilas Boas RC, Silva WG, Silva ALP (2012) Produtividade da alface americana submetida a diferentes lâminas de irrigação. Semin-Cienc Agrar. 33:2681-2688.

Lubana PPS, Narda NK (1998) Soil water dynamics model for trickle irrigated tomatoes. Agr Water Manage. 37:145161.

Moncef H, Khemaies Z (2016) An analytical approach to predict the moistened bulb volume beneath a surface point source. Agr Water Manage. 166:123-129.

Mosca MA, Testezlaf R, Gomes EP (2005) Desenvolvimento de emissores alternativos para irrigação subsuperficial de baixa pressão. Irriga 10:249-262.

Mou B (2008) Lettuce. In: Prohens J, Nuez F (eds) Handbook of plant breeding. Vegetables I. Asteraceae, Brassicaceae, Chenopodiaceae and Cucurbitaceae. New York.

Parkes M, Yao WW, Ma, XY, Li, J (2010) Simulation of point source wetting pattern of subsurface drip irrigation. Irrig Sci. 29:331-339.

Rajput TBS, Patel N (2009) Effect of subsurface drip irrigation on onion yield. Irrig Sci. 27:97-108.

Salomão LC (2008) Uniformidade do sistema de irrigação. In: Souza TR, Villas Boas RL, Saad JCC (eds) Aspectos práticos da fertirrigação, 3rd., Botucatu, São Paulo.

Silva MJD, Torres LHR, Alves JXS (2011) Enchente no município de São Luiz do Paraitinga - SP: Soluções construtivas utilizadas na proteção das margens do Rio Paraitinga. Paper presented at the IX symposium international of Integrated Sciences, University of Ribeirão Preto, São Paulo.

Singh DK, Rajput TBS, Sikarwar HS, Sahoo RN, Ahmed T (2006) Simulation of soil wetting pattern with subsurface drip irrigation from line source. Agric Water Manage. 83:130-134.

Souza CF, Matsura EE (2004) Distribuição da água no solo para o dimensionamento da irrigação por gotejamento. Rev Bras Eng Agríc Ambiental 8:7-15.

Van Genucthten's MTA (1980) Closed-from Eq for predicting the hydraulic conductivity of unsaturated soil. Soil Sci Soc Am J. 44:892-898.

Wei WY, Xiao YM, Juan L, Martin P (2011) Simulation of point source wetting pattern of subsurface drip irrigation. Irrig Sci. 29: 331-339. 